\title{
Changes in Zinc in Milk during Enzymatic Digestion
}

\author{
Hisao Matsui, Osamu Wada and Tetsu Ono \\ Department of Hygiene, Gunma University School of Medicine, Maebashi
}

\section{INTRODUCTION}

Zinc is known to be an essential element for human nutrition and good health ${ }^{11}$. Milk is its sole source in infants, and growing children as well as mature adults consume varying amounts of milk, which provide them with much of the needed zinc.

Investigators, using gel filtration chromatography ${ }^{2,3)}$, have demonstrated that zinc in cow's milk can be associated with fractions of high molecular weight, whereas zinc in human milk is bound to fractions of low molecular weight. A low molecular weight zinc-binding ligand has also been reported in human milk, which, however, is found only in very small amounts in cow's milk. This ligand may improve zinc absorption by normal neonates as well as by children with acrodermatitis enteropathica, a zinc metabolism disorder which is genetic. Hurley et $a .^{4}{ }^{4}$ have suggested that casein is the high molecular weight compound in cow's milk to which zinc mainly binds, and that such bound zinc is less available for absorption.

However, no attempt has been made to determine the form in which the zinc in milk can exist in the alimentary tract or the changes which occur on passage of the digesta along the tract. The chemical form of zinc during digestion affects its availability. In the present paper, the authors report the in vitro effects of digestive enzymes and $\mathrm{pH}$ on the forms of zinc in milk.

\section{MATERIALS AND METHODS}

\section{Samples of human and cow's milk}

Human milk was obtained from nursing mothers within three weeks after parturition. The milk was collected by hand expression into acid-washed glass or plastic containers and was stored at $-20^{\circ} \mathrm{C}$ until used. Unprocessed cow's milk was donated by a local dairy (Gunma Prefecture).

Reagents

Pepsin (2,870 units/mg protein) and trypsin (12,000 BAEE units/mg protein) were obtained from Sigma Chemical Co., Ltd.. All chemicals used were of reagent grade. Buffers and reagents were prepared in distilled water.

Enzymatic digestions

The milk was centrifuged at $1,500 \times g$ for $15 \mathrm{~min}$ and the fat-free supernatant was withdrawn. Aliquots of $1.0 \mathrm{~m} l$ of fat-free milk were mixed with equal volumes of enzymes prepared as follows : pepsin $(4.0 \mathrm{mg} / \mathrm{m} l)$ in $0.05 \mathrm{M}$ hydrochloric acid solution containing $34 \mathrm{mM} \mathrm{NaCl}(\mathrm{pH} 1.2) ; \operatorname{trypsin}(2.0 \mathrm{mg} / \mathrm{m} l)$ in $0.1 \mathrm{M} \mathrm{NaCl}$ /sodium bicarbonate solution $(\mathrm{pH} 8.3)$. To study the effects of $\mathrm{pH}$, aliquots $(1.0 \mathrm{~m} l)$ of fat-free milk were mixed with equal volumes of the above solutions without enzymes. All of the mixtures were incubated at $37^{\circ} \mathrm{C}$ for $60 \mathrm{~min}$. In addition, another aliquot $(2.0 \mathrm{ml})$ of the milk was incubated with a onehalf volume of pepsin solution, and then the mixture was digested with trypsin. After digestion, the reaction mixture was centrifuged at $12,000 \times g$ for $20 \mathrm{~min}$ and the supernatant obtained was filtrated on a dextran (Sephadex) gel.

\section{Gel filtration chromatography}

Separations were carried out on a $1.5 \times 30 \mathrm{~cm}$ column of Sephadex G-75 (Pharmacia Ltd., Uppsala), which had been pre-equilibrated with $10 \mathrm{mM}$ phosphate buffer $(\mathrm{pH} \mathrm{7.4)}$ containing $20 \mathrm{mM} \mathrm{NaCl}$. The samples were eluted with the same buffer at a flow rate of about $6 \mathrm{~m} l / \mathrm{hr}$ and $2.8 \mathrm{~m} l$-fractions were collected. The concentration of zinc in each fraction was determined by atomic absorption spectros- 
copy. Absorbance at $280 \mathrm{~nm}$ was measured for each fraction. The Sephadex G-75 column was calibrated with substances of known molecular weight - blue dextran, cytochrome $\mathrm{C}$, bacitracin, leucine, $\mathrm{Zn}\left(\mathrm{NO}_{3}\right)_{2}$.

\section{Metal analysis}

Zinc concentration was measured on a flameless atomic absorption spectrophotometer (Shimazu AA -650) equipped with a graphite furnace atomizer (Shimazu GFA-2). Five $\mu l$ samples were used in each

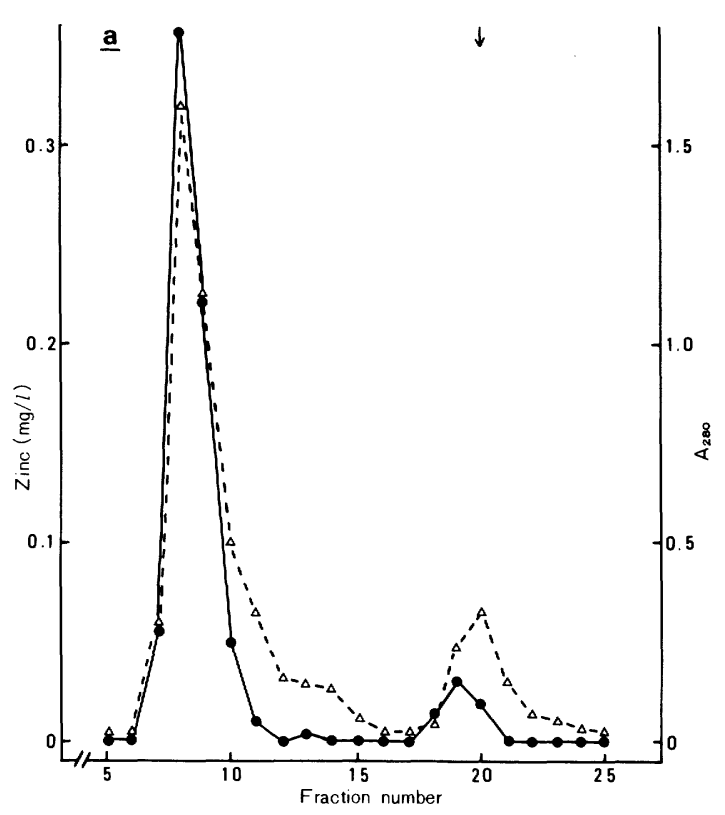

(a) Cow's milk before treatment.

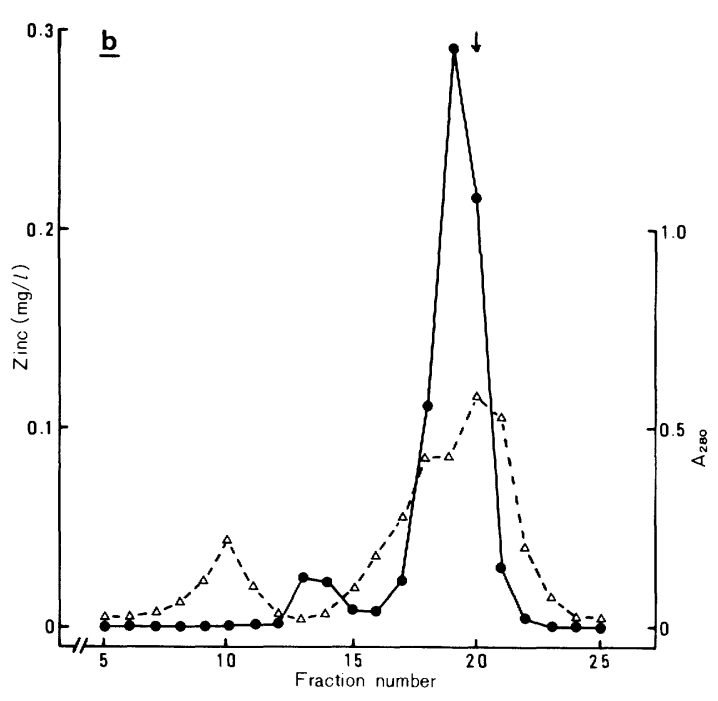

(b) Pepsin-digested cow's milk.

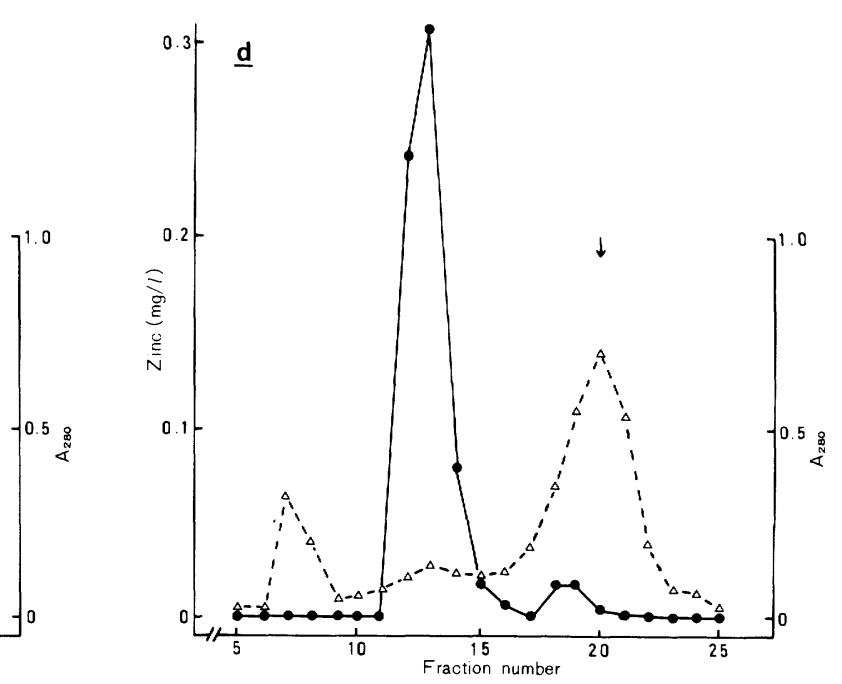

(d) Cow's milk digested sequentially by pepsin

and trypsin.

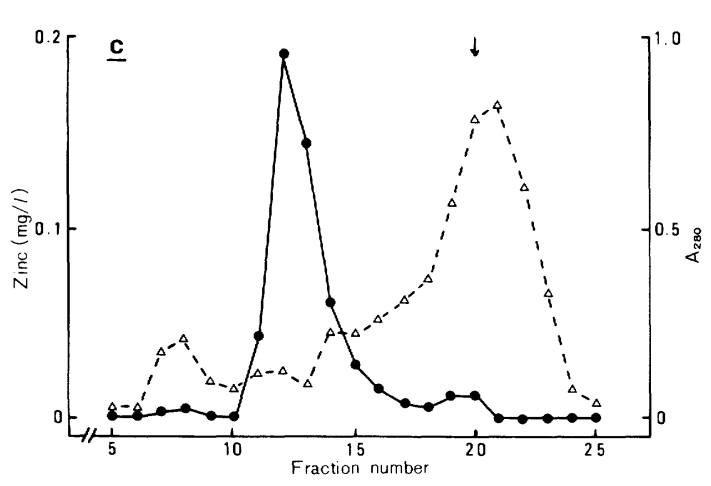

(c) Trypsin-digested cow's milk.

Fig. 1 Elution profiles of enzyme-treated cow's milk on a column of Sephadex G-75.

Concentrations of $z \operatorname{inc}(-)$, and $\mathrm{A}_{280}(\triangle \cdots \cdots \Delta)$, and the position of $\mathrm{Zn}\left(\mathrm{NO}_{3}\right)_{2}$ eluted $(\downarrow)$. 
analysis. Standard solutions were made by appropriate dilutions of the zinc with $1,000 \mathrm{mg} / l$ as the reference standard (Wako, Japan).

\section{RESULTS}

\section{Acid-peptic digestion}

Gel filtration on Sephadex G-75 of both defatted human and cow's milk showed two peaks (Fig. 1a,

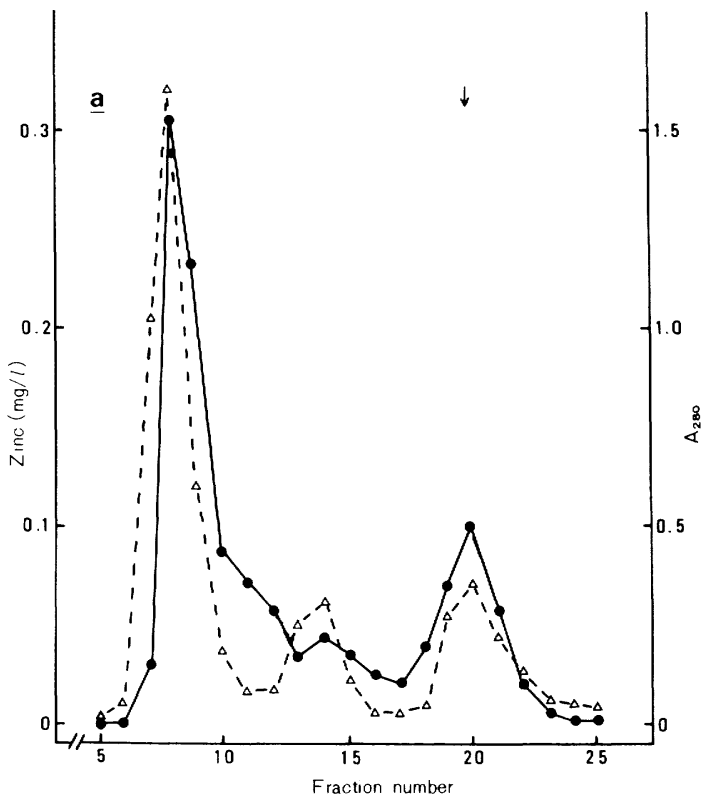

(a) Human milk before treatment.

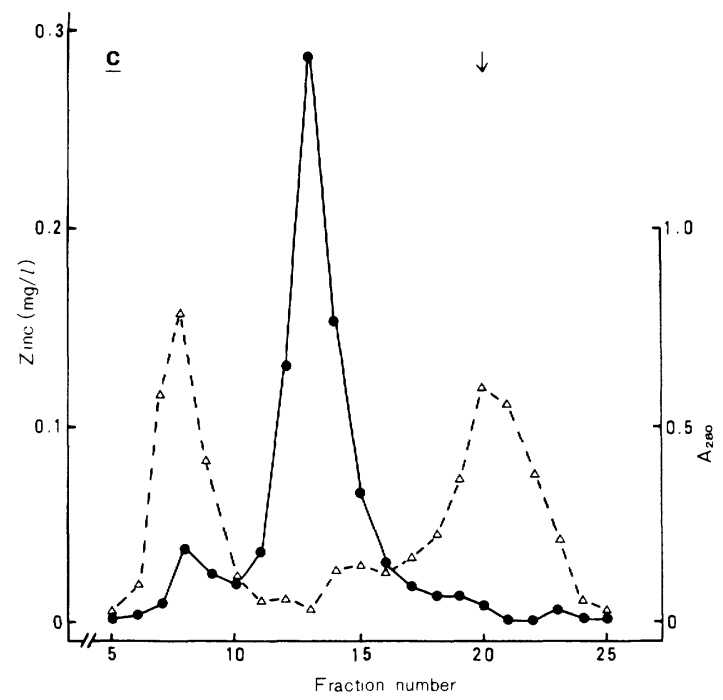

(c) Trypsin-digested human milk.

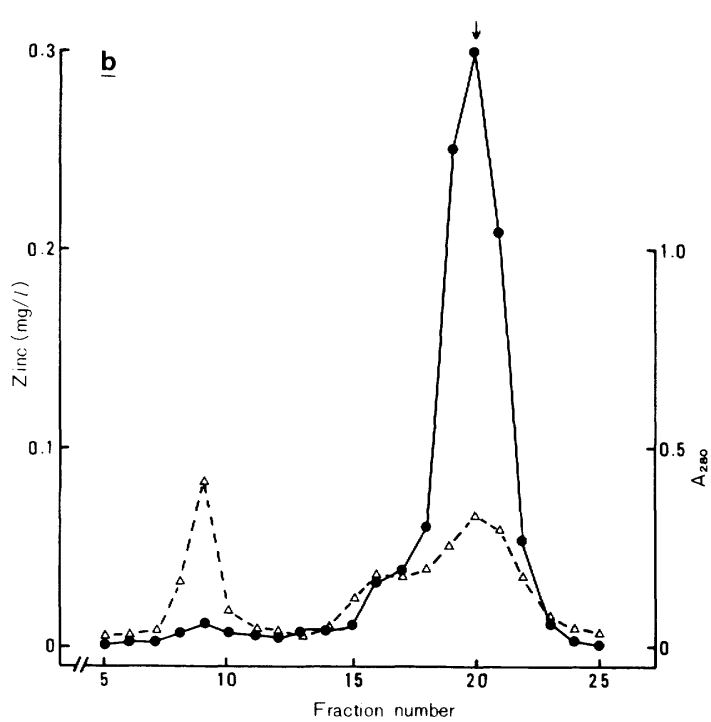

(b) Pepsin-digested human milk.

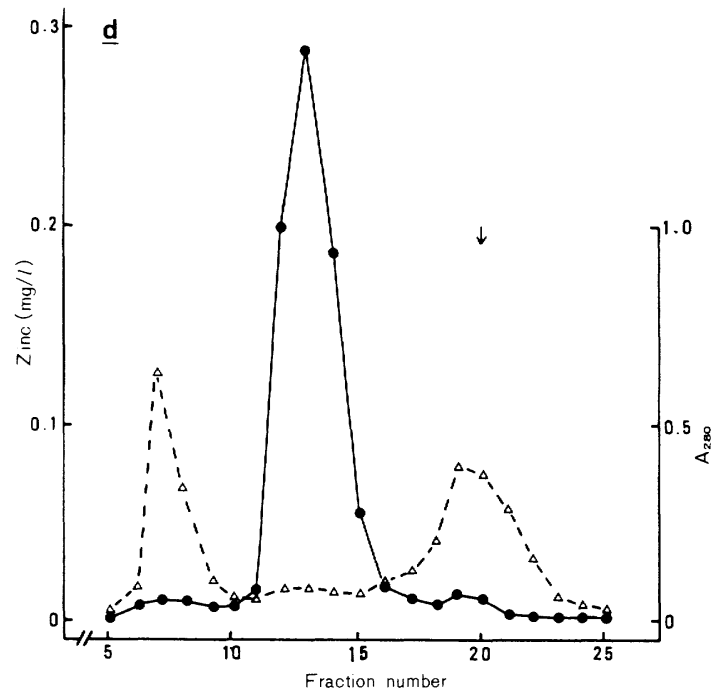

(d) Human milk digested sequentially by pepsin and trypsin.

Fig. 2 Elution profiles of enzyme-treated human milk on a column of Sephadex G-75. 


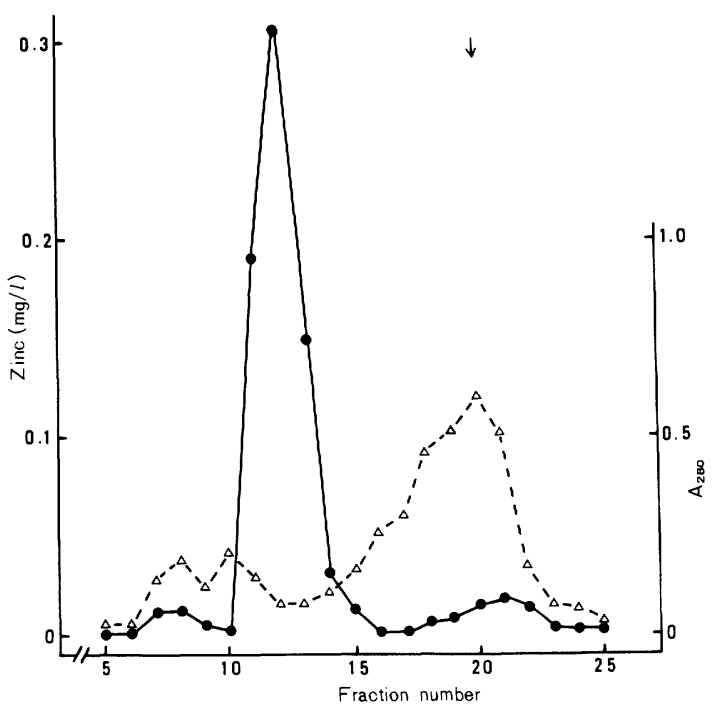

Fig. 3 The effects of $\mathrm{pH}$ on the elution profiles of pepsin-digested cow's milk.

Milk was adjusted to $\mathrm{pH} 8.3$ before gel filtration. Fig. 1b shows pepsin-digested cow's milk with no $\mathrm{pH}$ adjustment. Concentrations of zinc $(-)$, and $\mathrm{A}_{280}(\triangle \cdots \cdots \triangle)$, and the position of $\mathrm{Zn}\left(\mathrm{NO}_{3}\right)_{2}$ eluted $(\downarrow)$. 2a). Most of the zinc (cow's milk, $>90 \%$; human milk, $>70 \%$ ) eluted at the first peak which was located at the void volume of the gel. The second peak eluted at the column's total volume, where zinc was present in greater quantities in human milk obtained early in lactation than in cow's milk. During separation of pepsin-digested milk, the first peak disappeared and most of the zinc eluted at a volume similar to that observed for $\mathrm{Zn}$ $\left(\mathrm{NO}_{3}\right)_{2}$ (Fig. 1b, 2b). The zinc elution profiles obtained after pepsin digestion were similar for human and cow's milk. Changes in elution pattern were observed by adjusting the $\mathrm{pH}$ (8.3) of the peptic digest before gel filtration (Fig. 3). The zinc eluted at a volume slightly less than cytochrome $\mathrm{C}$ with a molecular weight of 12,000. However, an $\mathrm{HCl}$ solution with no enzymes gave a main zinc peak at the same place as those in pepsin-digested sam. ples. Adjusting the $\mathrm{pH}$ to 8.3 prior to gel filtration demonstrated that most of the zinc eluted at the void volume.

\section{Sequential treatments of milk with pepsin and trypsin}

Sequential digestion by pepsin and trypsin gave zinc elution profiles at a volume slightly less than that of cytochrome C (Fig. 1d, 2d). The position of the peak was similar to pepsin-digested milk with a $\mathrm{pH}$ adjustment. Milk treated with trypsin alone also gave a zinc elution profile similar to that of sequential digestion (Fig. 1c, 2c). As a control, a milk and $\mathrm{Zn}\left(\mathrm{NO}_{3}\right)_{2}$ solution $(5 \mathrm{mg} / \mathrm{m} l)$ was adjusted to a $\mathrm{pH}$ of 8.3, and there were no significant changes before and after treatment. There was no difference between human and cow's milk in terms of the amount of zinc at any time during the experiments.

\section{CONCLUSIONS}

In the present study, the effects of acid-peptic digestion on zinc in milk was studied to consider the possibility that hydrochloric acid and pepsin secreted by the gastric mucosa react with milk present in the stomach. Pepsin digestion in an $\mathrm{HCl}$ solution showed that most zinc eluted at a volume similar to that observed for $\mathrm{Zn}\left(\mathrm{NO}_{3}\right)_{2}$. Milk treated with an enzymeless $\mathrm{HCl}$ solution peaked at the same place as in pepsin-digested samples. The results suggest that in the stomach, zinc is either free or bound to low molecular weight moieties. Parkash and Jenness ${ }^{5)}$ have reported that most zinc in cow's milk is associated with casein, and casein-bound zinc is completely released by acidification to a $\mathrm{pH}$ of 2.0 .

Milk was then sequentially digested by pepsin and trypsin. Most zinc eluted at a volume slightly less than that of cytochrome $\mathrm{C}(12,000$ molecular weight). Moreover, pepsin-digested milk, adjusted to $\mathrm{pH} 8.3$ prior to gel filtration, had an elution profile similar to that of sequentially digested milk, suggesting that when pepsin-digested milk passes into the duodenum, zinc may bind to substance (s) with molecular weights of approximately 12,000 .

Hurley et al. ${ }^{2,4,7)}$ and Evans et al. ${ }^{3,6)}$ have demonstrated that human milk contains much zinc-binding ligands which may facilitate zinc absorption. However, changes in zinc were not reported during milk digestion.

The present experiments show that the digestion of human and cow's milk results in identical changes in elution profile. Zinc-binding substance (s), therefore, may be formed in the gastrointestinal 
tract, although digestion in vivo is perhaps not comparable to in vitro experiments using a simple enzyme system. Furthermore, it may be impossible to estimate zinc availability simply from its presence in raw milk.

It has been suggested that enzyme-resistant peptides are formed during the intestinal digestion of milk casein and that they can form complexes with various other substances ${ }^{8)}$. Mellander ${ }^{9)}$ demonstrated that the peptides form complexes with calcium $70 \%$ or more of which is then absorbed from the intestinal tracts of infants. To what extent these peptides form complexes with zinc is an interesting problem for further research.

Zinc-binding substance (s) here probably bind other metals as well. The extent to which the fraction obtained participates in the intestinal absorption of zinc is presently being investigated.

\title{
SUMMARY
}

The amount of zinc in human and cow's milk was evaluated in in vitro experiments using gel chromatography on Sephadex G-75 to simulate the action of gastrointestinal enzymes. The HCl-peptic digestion of both types of milk demonstrated that most of the zinc eluted at the same position as $\mathrm{Zn}\left(\mathrm{NO}_{3}\right)_{2}$. The sequential digestion of both types of milk by pepsin and trypsin demonstrated that most of the zinc eluted at a position corresponding to a molecular weight slightly less than 12,000 . The results suggest that zinc may be liberated in the stomach and that when the pepsin-digested milk passes into the duodenum, which has an alkaline $\mathrm{pH}$ and where trypsin is secreted, zinc may bind to substance (s) formed during intestinal digestion. There was no difference between the elution profiles of the two kinds of milk. This indicates that differences in zinc availability in human and cow's milk is not responsible for the molecular weight of zinc-binding substances.

\section{REFERENCES}

1) Underwood, E. J. : Trace Elements in Human and Animal Nutrition (4th ed.), pp. 196-242, Academic Press, New York (1977).

2) Eckhert, C.D., Sloan, M.V., Duncan, J. R. and Hurley, L. S. : Zinc binding : a difference between human and bovine milk, Science, 195, 789-790 (1977).

3) Evans, G.W. and Johnson, P.E. : Zinc-binding factor in acrodermatitis enteropathica, Lancet, II, 1310 (1976).

4) Hurley, L.S., Lönnerdal, B. and Stanislowski, A.G. : Zinc citrate, human milk, and acrodermatitis enteropathica, Lancet, I, 677-678 (1979).

5) Parkash, S. and Jenness, R. : Status of zinc in cow's milk, J. Dairy Sci., 50, 127-134 (1967).

6) Evans, G.W., Johnson, P.E., Brushmiller, J.G. and Ames, R.W.: Detection of labile zinc-binding ligands in biological fluids by modified gel filtration chromatography, Anal. Chem., 51, 839-843 (1979).

7) Lönnerdal, B., Stanislowski, A. G. and Hurley, L.S. : Isolation of a low molecular weight zinc binding ligand from human milk, J. Inorg. Biochem., 12, 71-78 (1980).

8) Mellander, O.: Protein quality, Nutr. Rev., 13, 161-163 (1955).

9) Mellander, O. and Isaksson, B. : The physiological importance of the casein phosphopeptide calcium salts. I. Intravenous and peroral calcium dosage in animal experiments, Acta Soc. Med. Upsal., 55, 239-247 (1950).

\section{消化による乳汁中亜鉛の存在形態の変化}

\author{
群馬大学医学部衛生学教室 \\ 松井寿夫・和田 攻・小野 哲
}

人乳および牛乳中の亜鉛が消化過程でどのような存在形態の変化を示すかを明らかにする目的で in vitro の実験で検 討した。人乳扔よび牛乳をペプシン，トリプシン，あるいはその両方で消化し，消化生成物を Sephadex G-75 でゲルろ 過クロマトグラフィーを行った。ペプシン消化では, 乳汁中亜鉛の大部分は $\mathrm{Zn}\left(\mathrm{NO}_{3}\right)_{2}$ と同じ位置に溶出した。また, 乳 汁を塩酸酸性にするのみでも同様に亜鉛の遊離がみられた。このことは，胃において乳汁中亜鉛が遊離することを示し 
ている。乳汁をペプシン消化した後, トリプシンで消化した場合には, 大部分の亜鉛はチトクローム C(分子量：12,000) よりわずかに早い位置に溶出された。また，ペプシン消化した乳汁を $\mathrm{pH} 8.3$ に調整した場合にも，ペプシン・トリプシ ンの連続消化したときと同样な溶出パターンを示した。これらのことから，アルカリ性の十二指腸中では垔鉛は消化生 成物と結合すると考えられる。また，消化後の亜鉛溶出パターンに人乳と牛乳とで差がみられなかったことは，人乳と 牛乳に扔ける亜鉛吸収率の差が亜鉛結合物の分子量の大きさによっているのではないことを示唆している。

Key words : Human milk, Cow's milk, Pepsin digestion, Trypsin digestion, Zinc 人乳, 牛乳, ペプシン消化，トリプシン消化，亜鉛 